\begin{tabular}{|l|l|l||}
\hline \multicolumn{2}{|c|}{ PublisherInfo } \\
\hline \hline PublisherName & $:$ & BioMed Central \\
\hline \hline PublisherLocation & $:$ & London \\
\hline \hline PublisherImprintName & $:$ & BioMed Central \\
\hline \hline
\end{tabular}

\title{
Caution-closed suction systems!
}

\begin{tabular}{|l|l|l||}
\hline \multicolumn{3}{|c||}{ ArticleInfo } \\
\hline \hline ArticleID & $:$ & 4298 \\
\hline \hline ArticleDOI & $:$ & $10.1186 /$ ccf-2001-73200 \\
\hline \hline ArticleCitationID & $:$ & 73200 \\
\hline \hline ArticleSequenceNumber & $:$ & 9 \\
\hline \hline ArticleCategory & $:$ & Paper Report \\
\hline ArticleFirstPage & $:$ & 1 \\
\hline ArticleLastPage & $:$ & 3 \\
\hline \hline & & RegistrationDate : 2001-12-3 \\
ArticleHistory & $:$ & Received \\
\hline ArticleCopyright & $:$ & Biomed Central Ltd2001-4-6 \\
\hline \hline ArticleGrants & $:$ & \\
\hline \hline ArticleContext & $:$ & 1305455 \\
\hline \hline
\end{tabular}




\section{Keywords}

\section{Context}

Closed suction systems have become popular in the airway toilet of critically ill patients who are intubated because they may reduce cross infection and prevent lung collapse and desaturation. The aim of this study was to examine their effect on ventilation using a plastic model of the lungs and trachea.

\section{Significant findings}

Open suctioning through a $7 \mathrm{~mm}$ endotracheal tube (ETT) resulted in alveolar pressures of $-7 \mathrm{~cm} \mathrm{H}_{2} 0$ with a $12 \mathrm{Fr}$ catheter. This fell to $-24 \mathrm{~cm} \mathrm{H} \mathrm{H}_{2} \mathrm{O}$ if a $14 \mathrm{Fr}$ catheter was used. During volume controlled modes, intrinsic positive end-expiratory pressure (PEEP) developed at levels up to $22 \mathrm{~cm} \mathrm{H}_{2} \mathrm{O}$ greater than externally applied PEEP during suction through a $7 \mathrm{~mm}$ tracheal tube with a 14 Fr catheter. Peak inspiratory pressures rose to as high as $50 \mathrm{~cm} \mathrm{H}_{2} \mathrm{O}$.

Pressure controlled ventilation by contrast was much safer. Intrinsic PEEP levels of just $5 \mathrm{~cm} \mathrm{H}_{2} \mathrm{O}$ greater than PEEP were generated, associated with a reduction in alveolar ventilation. Continuous positive airway pressure (CPAP) appeared best with minimal changes in alveolar pressure during closed system suctioning.

\section{Comments}

A vital aspect of protective lung ventilation as advocated in the ARDSnet study is alveolar recruitment and the maintenance of PEEP. Contrary to perceived wisdom closed suction systems may actually cause more marked swings in alveolar pressures, particularly during volume controlled modes of ventilation. Further comparisons between closed and open suction catheter systems are therefore 
necessary to determine the overall effect of closed suction systems with a variety of ventilatory modes from alternative ventilators.

\section{Methods}

Lung model with rigid plastic trachea, ventilation with a Servo, alveolar and tracheal pressures were measured

\section{Additional information}

\section{References}

1. Stenqvist O, Lindgren S, Karason S, Sondergaard S, Lundin S: Warning! Suctioning. A lung model evaluation of closed suctioning systems. Acta Anaesthiol Scand. 2001, 45: 167-172. 